\title{
Some Names in Pan Chou San Mei Ching
}

\section{Asao Iwamatsu}

One of the most important sutras of early Mahayana Buddhism is Pan Chou San Mei Ching 般舟三昧経 (hereafter PSC), the Sanskrit name of which, derived from Tibetan translation, is Pratyutpannabuddhasammukhãvasthitasamädhisütra (hereafter PraS). Regarding this Ching, Ch'u San Tsang Chi Chi 出三 蔵記集 tells us that two texts were translated under the same or quite similar title: one by Chih Lou Chia Ch'an 支婁迦驖 (or Chih Ch'an 支域 for short) in 179 A. D.; and the other by $\mathrm{Chu} \mathrm{Fa} \mathrm{Hu}$ 筑法護, probably in the late half of third century A. D. The former is said to be of one Chüan 巻 (but in Sung, Yüan and Ming editions, it is said to be of two Chüan) and is titled Pan Chou Pan San Mei Ching 般舟般三昧経 (but in Sung, Yüan and Ming editions, it is simply called Pan Chou San Mei Ching); and the latter is said to consist of two Chüan and is titled Pan Chou San Mei Ching. Now we have two texts of this same title "Pan Chou San Mei Ching." One of them is of three Chüan (Taisho no. 418, hereafter $\mathrm{PSC}^{3}$ ), and the other is of only one Chüan (Taisho no. 417, hereaf. ter PSC $^{1}$ ). Both of them are said to be translated by the same Chih Lou Chia Ch'an. But there remain some doubts about the translatership of these texts, and, as regards the latter, even whether it is really a translation. One reason is that the latter $\left(\mathrm{PSC}^{1}\right)$ is contained only in the Kao $\mathrm{Li}$ edition whereas the former is contained in every edition of Sung, Yüan and Ming as well as Kao $\mathrm{Li}$; and, at one glance, seems to be not a translation but an extract of the former or such. For these and some other reasons there are various opinions about the translation and translatership of these texts. There is no space here for introducing all of these views. Here I would like to follow the widely held opinion which considers the former $\left(\mathrm{PSC}^{3}\right)$ to have been translated by Chih Lou Chia Chan himself and the latter ( $\mathrm{PSC}^{1}$ ) to have been translated, or rather, abridged by an unknown person.

There are two other Chinese translations of PraS. One of them is $\mathrm{Pa} \mathrm{P}^{\prime} \mathrm{o}$ 
$P^{\prime} u S a$ Ching 抜陂菩薩経 (Taisho no. 419, hereafter PP'C), the translater of which, according to the catalogue of Buddhist works, is unknown (Shih I 失訳). The other is Ta Fang Têng Ta Chi Ching Hsien Hu Fên 大方等大集経賢護分, the Sanskrit title of which is reconstructed as Mahãvaipulya-mahāsamnipātasütra-Bhadrapäla-parivarta (Taisho no. 416, hereafter HHF), and which was translated by Jñānagupta in 594-5 A. D.

The Sanskrit text of PraS is entirely unknown except for one fragment, which was published by S. Konow in R. Hoernle's Manuscript Remains of Buddhist Literature. But it has no particular bearing on our present study. PraS is also translated into Tibetan probably from the Skt. original and is contained in the Tibetan Tripitaka (Bkah hgyur). Recently this Tibetan text of PraS was published in typescript by Mr. P. M. Harrison ("The Tibetan Text of the PratyutpannaBuddha-Saṃmukhāvasthita-Samādhi-Sūtra”, Studia Philologica Buddhica Monograph Series I, Tokyo, the Reiyukai Library, 1978; hereafter TPraS).

In PSC also, as it is usual in Chih Lou Chia Ch'an's translation, we find many Indian words, not only proper names but also some technical terms, remaining untranslated; that is, transliterated. Most of the Skt. equivalents of these transliterated words can be known by comparing these words with Tibetan, though the texts (PSC and TPraS) themselves are not quite the same. It is apparent that the original text of PSC was written not in classical Sanskrit but in Prakrit; and considering the old pronunciation of the characters of these transliterated words we can conjecture, to a certain extent, their original Prakritic form. In this article I would like to treat of Skt. originals of some proper names in PSC, and, if possible, their Prakritic form.

The PraS begins with the story that eight bodhisattvas come from their home cities to visit the Buddha who is staying on the Mt. Gṛdhrakūta. Most of these bodhisattvas are found in some other Mahayana sutras among the sixteen satpurușas or among the Buddha's attendants; e. g., in Pañcaviṃśatisāhasrikā (hereafter Pv), Śatasāhasrikā (hereafter Ś) and Saddharmapuṇdarīka (hereafter $\mathrm{SP}$; only in Sankrit text) and their various translations.

The eight bodhisattvas in PSC and their correspondents are given in the next page. 
Some Names in Pan Chou San Mei Ching (A. Iwamatsu)

Names of eight bodhisattvas in $\mathrm{PSC}^{3}$ and their equivalents

\begin{tabular}{|c|c|c|c|c|c|c|}
\hline & $\mathrm{PSC}^{3}$ & TPraS & Skt. equiv. & \multicolumn{3}{|c|}{$\mathrm{PSC}^{1}$} \\
\hline 1) & 馛陀和 & bzan் skyon் & bhadrapāla & 成 & 陀 & 和 \\
\hline 2) & 羅憐那竭1) & dkon் mchog ḥbyun gnas & ratnākara & 羅 & 隣 那 & 竭 \\
\hline 3) & 橋 日 㬱 ${ }^{2)}$ & phug sbas & guhagupta & 憍 & 日 & 軼 \\
\hline 4) & 那 羅 達 & hadam bus byin & naḍadatta & 那 & 羅 & 達 \\
\hline 5) & 須 深 & mtshams bzan் & susīma & 須 & & 墚 \\
\hline 6) & 摩訶須薩和 & ded dpon chen po & mahāsārthavāha & 摩 & 訶須 薩 & 和 \\
\hline 7) & 因坻 達 & dbań pos byin & indradatta & 因 & 坻 & 達 \\
\hline 8) & 和 輪 調3) & chu lha & varuṇa & 和 & 輪 & 調 \\
\hline
\end{tabular}

\begin{tabular}{|c|c|c|c|c|}
\hline $\mathrm{PP}^{\prime} \mathrm{C}$ & $\mathrm{HHF}$ & $\mathrm{Pv}$ & $\dot{S}$ & $\mathrm{SP}$ \\
\hline 陂 & 賢 & bhadrapāla $(1)^{8)}$ & bhadrapāla $(1)^{9)}$ & bhadrapāla(1) \\
\hline 羅 檀 迦篥 & 生 ${ }^{5)}$ & ratnākara(2) & ratnakara(2) & ratnākara(2) \\
\hline 迦 休 頭 & 藏我 & śubhagupta(6) & guhagupta(7) & guhyagupta(5) \\
\hline 那 達 頭 & 那羅 達 多 & naradatta(4) & naradatta $(6)$ & naradatta(4) \\
\hline 須 深 無 & & & & \\
\hline 大大導衆) & 大善商主 ${ }^{7)}$ & sārthavāha(3) & susārthavāha(5) & susārthavāha(3) \\
\hline 達 & 偉 & indradatta(7) & indradeva $(9)$ & indradatta(7) \\
\hline 謾 論 調 & 水 & varuṇadatta(5) & varuṇadeva(8) & varuṇadatta(6) \\
\hline
\end{tabular}

\begin{tabular}{|c|c|c|c|c|c|c|c|c|}
\hline \multicolumn{2}{|r|}{ FKC } & KTC & \multicolumn{2}{|c|}{ MPC } & \multicolumn{2}{|c|}{ CTL } & \multicolumn{2}{|c|}{$\mathrm{TPC}(3)$} \\
\hline 護 & 諸 繫 $(1)^{10)}$ & 颩 陀 和 $(1)^{11)}$ & 颰陀婆 & 羅 $(1)^{14)}$ & 颰陀婆 & 羅 $(1)^{18)}$ & 賢 & 守(1) \\
\hline 宝 & 来(2) & 羅 隣 那 竭(2) & 罣 那 伽 & 羅 $(2)^{15)}$ & 宝 & 樍 $(2)^{17)}$ & 宝 & 性(2) \\
\hline 所孚 & 受則能説(5)? & 嬌 日 览 $(5)^{12)}$ & 星 & 得(5) & 星 & 得(3) & 星 & 授 $(5)$ \\
\hline 竜 & 施(4) & 那 羅 達(4) & 羅 & 達(4) & 那 & 達(5) & 仁 & 授 $(4)$ \\
\hline 導 & 師(3) & 摩訶須菩和 $(3)^{13)}$ & 導 & 師(3) & 導 & 師(4) & 導 & 師(3) \\
\hline 天 & 王(7) & 坻(7) & 主 & 天(7) & & & 帝 & 授(7) \\
\hline 雨 & 天 $(6)$ & 和輪 & 水 & 天(6) & 水 & 天(6) & 水 & 天 $(6)$ \\
\hline
\end{tabular}

\begin{tabular}{|c|c|c|c|c|c|c|c|c|c|c|c|}
\hline \multicolumn{2}{|c|}{$\mathrm{TPC}(2)$} & \multicolumn{2}{|c|}{$\mathrm{TPC}(1)$} & \multicolumn{2}{|c|}{$\mathrm{CHC}$} & \multicolumn{3}{|c|}{ SIC } & \multicolumn{3}{|c|}{ SWC } \\
\hline 賢 & 護(1) & 賢 & 守(1) & 賢 & 護(1) & 跋 & 陀 婆 & 羅(1) & 跋 & 陀 婆 & 羅(1) \\
\hline 宝 & 性(2) & 宝 & 性(2) & 宝 & 事(2) & 宝 & & 積(2) & 宝 & & 積(2) \\
\hline 星 & 授(5) & 星 & 授(7) & & & 星 & & 徳(3) & & & \\
\hline 仁 & 授(4) & 仁 & 授 $(6)$ & 恩 & 施(3) & & & & 人 & & 德(4) \\
\hline & & & & 賢 & 力 $(6)$ ? & 善 & & 力 $(6)$ ? & 善 & 護 & 德(5)? \\
\hline 導 & 師(3) & 導 & 師(5) & 善 & 導(14) & 導 & & 師(14) & 善 & 将 & 導(3) \\
\hline 常 & 授 $(6)^{18)}$ & 帝 & 授 $(9)$ & 帝 & 天(4) & 帝 & & 天(4) & 帝 & 釈 王 & 徳(7) \\
\hline & & 神 & 授( $(8) ?$ & 水 & 天(5) & 水 & & 天(5) & 大 & 海 & 徳(6) \\
\hline
\end{tabular}


denotation :

$\mathrm{FKC}=$ 放光般若経（T 221）

$\mathrm{KTC}=$ 光 讃 経 $(\mathrm{T}$ 222)

$\mathrm{MPC}=$ 摩訶般若波羅蜜経（T 223）

$\mathrm{CTL}=$ 大智度論 $(\mathrm{T}$ 1509)

TPC =大般若波羅蜜多経 (T 220); the number indicating the Hui 会

$\mathrm{CHC}=$ 持心梵天所問経（T 585）

$\mathrm{SIC}=$ 思益梵天所問経（T 586）

$\mathrm{SWC}=$ 勝思惟梵天所問経（T 587）

v. 1. and notes:

1) 憐二粼

2）橋日 =憍目，憍日，憍曰

3）輪二倫，論

4) 大大 $=$ 大

in other place 宝徳, 宝得 6) in other place 伽訶苃多, 星徳 7) in other place 商主, 善商主 8) the number indicating the order 9) also appearing in 10th position 10) in 8th position 賢護 11) in 8th position 賢守 12) 嬌日二橋曰，橋日，嬌曰 13） probably miswriting of 摩訶須薩和 14）阔发二跋

15）犀=刺 16） in other place 善守 17) in other place 刺那(那) 伽羅

18) probably miswriting of 帝授

[Original names of the eight bodhisattvas]

(1) 题陀和 There is no doubt about its Skt. equivalent bhadrapāla. It is interesting that this bhadrapala is translated into Chinese as 護諸繫 in Fang Kuang Pan Jo Ching 放光般若経. This 護諸繫 leads us to suppose that its original in Skt. was something like baddhapāla. The old phonetic of 越陀和 is reconstructed by B. Karlgren ("Grammata Serica Recensa") as b'wât(pirwăt)-d'â-g'wâl b'uât

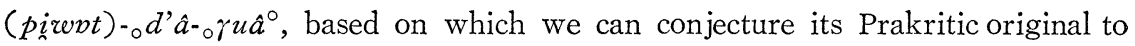
have been something close to bhaddavā(la).

（2）羅憐那竭 Here too there is no doubt about the Skt. equivalent, ratnāka-

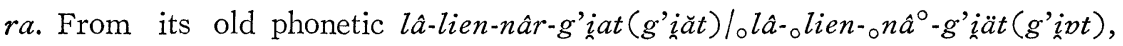
we can conjecture the original as something like $\operatorname{rat}[i$ or $a] n a \bar{g} a r(a)$. It seems that the intermediate $t$ has been cerebralized to $t$ or $d$ and that the consonant cluster $t n$ has been divided by an intervening vowel such as $i$ or $a$.

（3）橋日兒 (v. 1. 憍目兒, 憍日兒, 憍曰兒) There are many doubts about its Skt. equivalent guhagupta. Among the texts only Ś supports guhagupta, but no other texts seem to support it directly; for the reason being that on one

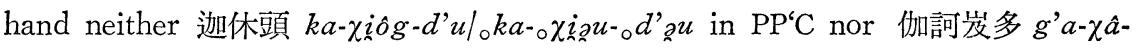

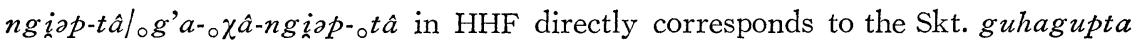
or its expected Indian form, and that on the other hand it is doubtful whether guha has the meaning 星 “star" which is found in such translation as 星蔵, 


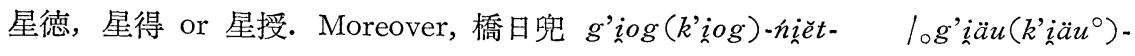

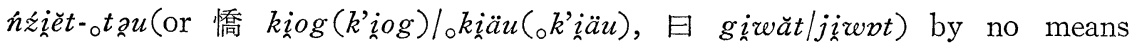
seems to represent the Indian form of guhagupta or Skt. itself. Yet it is not quite impossible to suppose that its Skt. equivalent was guhagupta, were the

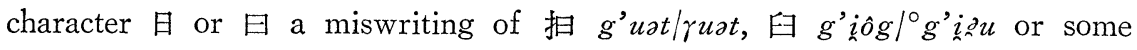
similar character; in which case its original would have been something like $g u h(a)-g u t(t) o$. In any case there remain many doubts about this name.

(4) 那羅達 Though the TPraS indicates that its Skt. form is nadadatta, this is dubious. That its Skt. equivalent should be naradatta is supported by $\mathrm{Pv}, \hat{\mathrm{S}}$ and SP. The Chinese translation 竜施 “dragon-given” makes us suppose a Skt. equivalent like nāgadatta. In any case, based on its old phonetic nâr-lâ-d'at $\left(t^{\prime} \hat{a} t\right) /{ }_{0} n \hat{a}^{0}{ }_{0} l \hat{a}$-d'at $\left(t^{\prime} \hat{a} t\right)$, we can conjecture its original to have been such as naradat $(t a)$.

(5) 須樑 Though the equivalent of this 須深 is lacking in HHF as well as in Pv, Ś, SP and their Chinese translations, based on TPraS it seems that its Skt. equivalent was susima. But the old phonetic rendering of 須媣, sinu-siżm/osiu${ }_{\circ} s_{i j a m}{ }^{\circ}$, suggests that the second $s$ was not kept unchanged, but rather was palatalized into $s$, probably under the influence of the succeeding palatal vowel $\bar{i}$. Thus we can conjecture its original to have been such as $\operatorname{susis} m(a)$.

(6) 摩訶須薩和 Though the Skt. equivalent known from TPraS is mahāsārthavaha, the character 須 no doubt indicates the existence of medial -su-. 大 善商主 in HHF also supports this medial -su-. Thus the Skt. equivalent of this 摩訶須薩和 ought to be not mahāsārthavāha but mahāsusārthavāha. From its

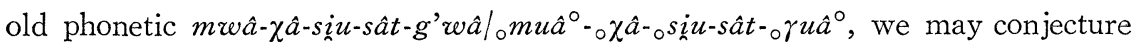
that the original had a form like mahāsusat $(t h a) v \bar{a}(h a)$.

（7）因坻達 It is interesting that in S its equivalent appears as indradeva, which would support the justice of the Chinese translation 天王, 天 or 主帝天. But in this case the Skt. equivalent is undoubtedly indradatta. From its old

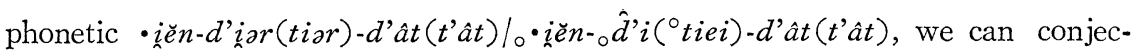
ture its original to have been something like ind $[i$ or $a] r(a) d a t(t a)$.

(8) 和輪調 In the Skt. text of Pv and SP varunadatta appears as the' correspondent of 和輪調. But in Ś its correspondent is not varunadatta but va- 
runadeva, which would be the Skt. equivalent of 和輪調. The Tibetan equivalent in TPraS is chu tha. I do not know whether it is a translation of the Skt. varunadeva or merely varuna. From its old phonetic g'wâ-linwan-d'iog (tîno $g$ )/ ${ }_{\circ} \gamma u \hat{a}^{\circ}{ }_{0}$ olinuén-od'ieu ${ }^{\circ}\left({ }_{0} \hat{t} i \partial u\right)$, we may conjecture its original to have been something like varun $(a) \operatorname{dev}(a)$. I have been interested in 謾論調 in $\mathrm{PP}^{\prime} \mathrm{C}$, the first character of which, that is 謾 $m w a ̂ n(m a n, m i a n) / 。 m u a ̂ n^{\circ}\left({ }_{\circ} m a n^{\circ}\right.$, 。miän), seemed to me to indicate the phonetic change $v / m$ even in the initial position (under the influence of remote nasal $n$ ?). But here it is not the main subject.

In $\mathrm{PSC}^{3}$ still remain far more words which require further investigation. Through careful consideration we might be able to reach a lot of interesting conclusions. There is not sufficient space here for discussing all of these matters. Then, I would like to close this short article after giving below some of these words as a material of our further investigation.

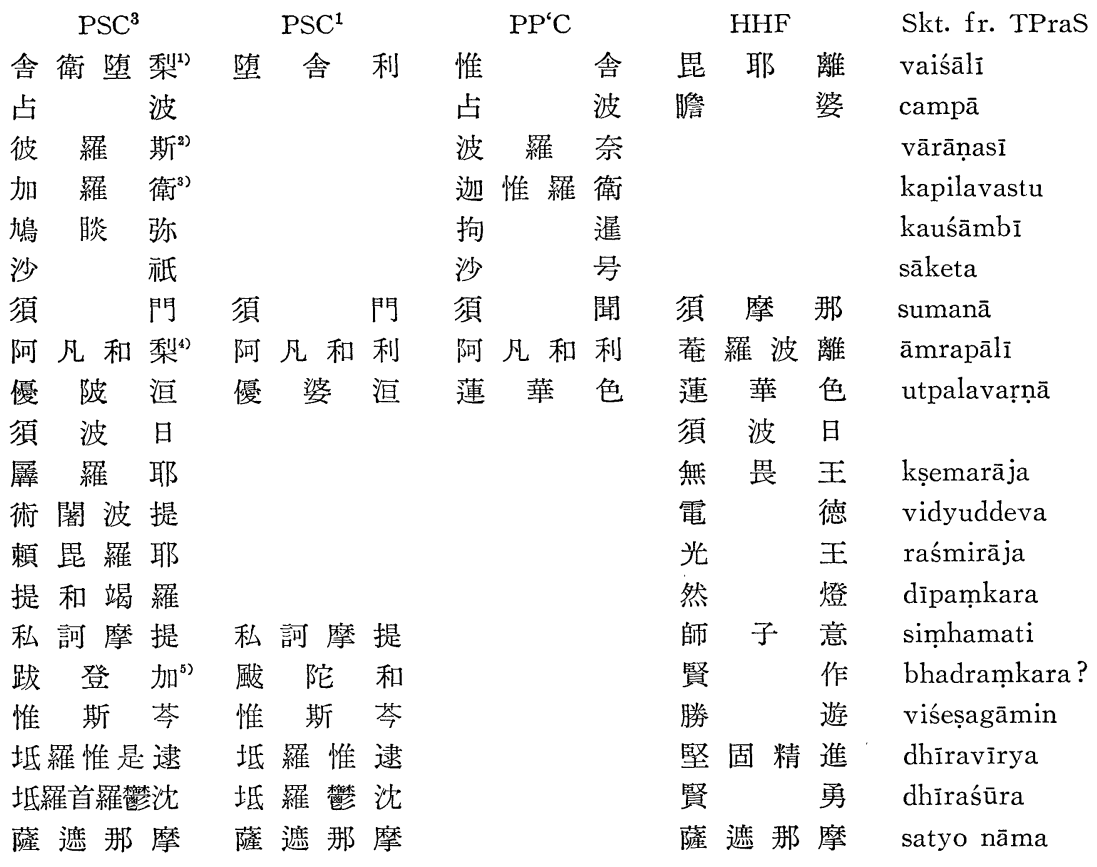
v. 1 .
1) $=$ 椨舎利, 随舎利
2) 彼=波
3) 加 $=$ 迦
4) 梨 $=$ 利
5） 登加 $=$ 発迦 